\title{
CORRIGENDUM
}

\section{HERC2 coordinates ubiquitin-dependent assembly of DNA repair factors on damaged chromosomes}

\section{Simon Bekker-Jensen, Jannie Rendtlew Danielsen, Kasper Fugger, Irina Gromova, Annika Nerstedt, Jiri Bartek, Jiri Lukas \& Niels Mailand}

Nature Cell Biol. 12, 80-81 (2010); published online 20 December 2009; corrected after print, 10 March 2010

In the version of this Letter initially published, an author, Claudia Lukas, was omitted. The author list and author's affiliations have been changed to:

Simon Bekker-Jensen ${ }^{1,3,4}$, Jannie Rendtlew Danielsen ${ }^{1,3,4}$, Kasper Fugger ${ }^{1}$, Irina Gromova ${ }^{2}$, Annika Nerstedt ${ }^{1}$, Claudia Lukas ${ }^{1}$, Jiri Bartek ${ }^{1}$, Jiri Lukas $^{1} \&$ Niels Mailand ${ }^{1,3}$

This change has been introduced in the html and PDF versions of the paper. 